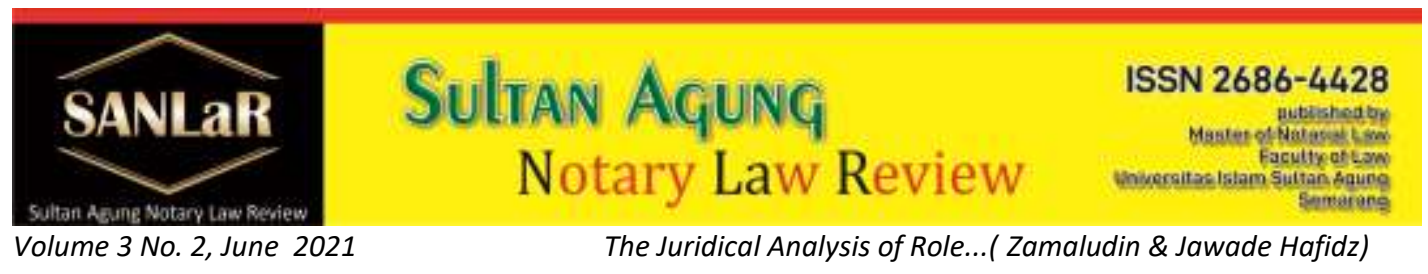

\title{
The Juridical Analysis of Role \& Responsibility of Notaries in Dispute Settlement with Mediation
}

\author{
Zamaludin $^{*}$ and Jawade Hafidz ${ }^{* *}$ \\ *) Faculty of Law, Universitas Islam Sultan Agung (UNISSULA) Semarang, E-mail: \\ zamaludin74@gmail.com \\ ${ }^{* *}$ Faculty of Law, Universitas Islam Sultan Agung (UNISSULA) Semarang, E-mail: \\ jawade@unissula.ac.id
}

\begin{abstract}
This journal will explore and discuss in order to be able to analyze and be able to find out about Juridical Analysis of the Role and Responsibilities of Notaries in Settlement of Disputes by Mediation/Peace. In this case Problem A peace deed is an agreement between two or more parties in which they request legal force assisted by a mediator in accepting and carrying out the contents of the agreed agreement. Peace decisions have executive power as described in Article 1858 of the Civil Code (hereinafter referred to as the Civil Code), Article 130 HIR paragraphs 2 and 3. Based on this, the peace agreement resulting from a dispute resolution process must be stated in written form, it aims to prevent the re-emergence of the same dispute in the future. This legal research aims to find out what is the role of a notary in settlement with peace outside the court and how is the responsibility of a notary in resolving disputes against a peace deed made before a notary and what is the legal force of a peace deed made before a notary. In this case deed of peace can be in the form of an underhand deed or an authentic deed made by a notary. This research is a normative juridical research that is used is the approach, namely: the juridical approach is used for research that refers to existing literature studies or to the secondary data used. While the normative approach is used to obtain normative knowledge about the relationship between one regulation and another and its application in practice. Types of legal materials used: Primary Legal Materials, Secondary Legal Materials and Tertiary Legal Materials obtained through literature study and data obtained from related parties. That is in Juridical Analysis of the Roles and Responsibilities of Notaries in Settlement of Disputes Amicably.
\end{abstract}

Keywords: Juridical; Roles; Responsibilities; Mediation; Peace.

1. Introduction

A muslim is called imperfect if he has not shown a commitment to maintaining the peace and safety of others or the environment. The ideals or good intentions 
of every Muslim must also be achieved in a way that does not hurt or interfere with the safety of others. In terms of language, the word 'salām' in the hadith means besides greeting others or greeting in Indonesian, it can also be interpreted as peace. The suggestion to spread greetings according to the above hadith is like an order to sow peace between people.

Reconciliation or ishlāh is therefore highly emphasized in Islam. The progress of a nation is determined by the spirit of its citizens to make peace, to stop fighting and fight to lead to a peaceful state. It is not a matter of success or failure of a people in seeking islah which is calculated by Allah. What is seen by the Almighty is how high the level of human hard work in realizing reconciliation between conflicting groups. Reconciling people who are in disagreement is not an easy matter because each party must be filled with their respective egos. However, Muslims can imitate the Prophet Muhammad who almost all his life always strive for peace between the warring Arab tribes.

In Al-Quran Surah Al-Hujurat verse 10 Allah SWT. Says:

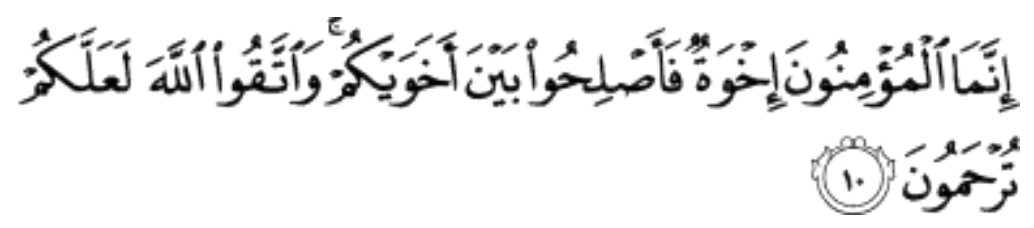

"The believers are but one brotherhood, so make peace between your brothers. And be mindful of Allah so you may be shown mercy." (Surah Al-Hujurat: 10).

Through this verse, Allah SWT. reminded that all forms of disputes between human beings should be treated fairly and the best way out and acceptable to the parties involved should be sought.

As social beings, humans always have relationships with other humans where in every relationship there is a law in which there are rights and obligations, sometimes conflicts and disputes arise that enter into the legal relationship. Laws that play a role in every human life can regulate or change a value system and perspective in a community group.

This friction between individuals can be caused by various things, often because one party feels aggrieved. In addition, feelings of dissatisfaction from one party can also trigger friction between individuals. This friction causes conflicts and disputes both between individuals and between groups in society. ${ }^{1}$

${ }^{1}$ http://eprints.unram.ac.id/5685/1/SKRIPSI.pdf, accessed on June 10, 2020 at 06:40 
The social impact of the dispute is the occurrence of social estrangement among community members, including obstacles to the creation of cooperation between them. The result is a decrease in the quality of environmental resources that can harm the interests of many parties. ${ }^{2}$ Disputes begin when one party feels aggrieved by the other party. When the party who feels aggrieved conveys his satisfaction to the second party and the second party shows a difference of opinion, a dispute or dispute occurs. ${ }^{3}$ Disputes can be resolved through formal means that develop into an adjudication process consisting of a process through court and arbitration or informal means based on the agreement of the disputing parties through negotiation and mediation. ${ }^{4}$ In Indonesian society itself, the settlement of disputes requires an effort to resolve them, both through court settlements (litigation) using formal legal provisions or through efforts outside the court (non-litigation). There are efforts to find ways of settlement that prioritize compromise, starting when looking at the forms of settlement used at that time (especially the judiciary) showing various weaknesses/lacknesses, such as: high costs, length of examination process, and so on.

Due to the increasing negative effects of the judiciary, this effort is known as an out-of-court settlement (non-litigation). This condition then prompted the birth of the provisions of Act No. 30 of 1999. In the event that a Notary becomes a mediator, the Notary is bound by the provisions of Act No. 2 of 2014 concerning Amendments to Act No. 30 of 2004 concerning the Position of a Notary (hereinafter referred to as the Notary Law) interfere with their performance in addition to being prohibited from having a side job that can cause a conflict of interest (conflict interesting). ${ }^{5}$

Peace itself is principally regulated in the laws and regulations in Indonesia, specifically in the Civil Code ("KUHPerd"), the Civil Procedure Code ("RAP"), and the Updated Indonesian Regulation ("HIR"). In addition, the concept of peace is spread across various other laws and regulations, including the law on the settlement of industrial relations disputes, the law on arbitration and alternative dispute resolution, and the law on bankruptcy and suspension of debt payment obligations.

In Article 1851 of the Criminal Code it is regulated that:

\footnotetext{
2 Maria SW Sumardjono, Nurhasan Ismail, Isharyanto, Mediasi Sengketa Tanah, Kompas, Gramedia, Jakarta, 2008, p. 3.

${ }^{3}$ http://repositori.usu.ac.id/bitstream/handle/123456789/483/147011135.pdf?sequence=1\&isAll owed=y

${ }^{4}$ Rachmadi Usman I, 2003, Pilihan Penyelesaian Sengketa di Luar Pengadilan, PT. Citra Aditya Bakti, Bandung, p. 3.

${ }^{5}$ https://media.neliti.com/media/publications/164877-ID-analysis-yuridis-atas-peran-notaristerh.pdf
} 
Peace is an agreement in which both parties, by surrendering, promising or withholding an item, end a case that is currently dependent or prevent a case from arising. From this understanding, it is clear that peace can end things that already exist or things that may exist in the future.

Furthermore, in paragraph (2) of Article 1851 it is stated that:

A peace agreement is not valid, if it is not made in writing. In other words, what is meant by a "peace agreement" is an agreement that must be made in writing, if you want to have legal consequences as regulated in the legislation. ${ }^{6}$

A notary is a state official who carries out state duties, the deed he makes is a state document. So the main task of the Notary is to make authentic deeds to serve the public at the request of the community. Notary is a profession that is open to law graduates or notary degree graduates. Notaries must be honest and loyal to each party and only by working in this way can he expect an award. A Notary must also protect the interests of customers. In the regulation of Act No. 2 of 2014 concerning Amendments to Act No. 30 of 2004 concerning the Position of a Notary, it is stated that in carrying out his duties and position a Notary must have integrity and act professionally, a Notary is obliged to carry out his position in a trustworthy, honest, thorough, independent and impartiality, ${ }^{7}$

In the event that a Notary becomes a mediator, the Notary is bound by the rules of Act No. 2 of 2014 concerning Amendments to Act No. 30 of 2004 concerning the Position of a Notary (hereinafter referred to as the Notary Law). prohibited from having a side job that may cause a conflict of interest (conflict interest).

The mediation process carried out by a Notary as a mediator is very possible considering that the Notary understands the problems that occur between the disputing parties who are his clients. Another advantage if the Notary acts as a mediator is that it will be easier to find a way out of the problem because the Notary understands the direction of the settlement to be chosen, this is because the Notary is the maker of the peace deed of the disputing parties, so he really understands the essence and context of the problems that are happening .

The main authority of a notary is to make an authentic deed. The authenticity of a notarial deed comes from Article 1 of the Notary Position Regulations where

\footnotetext{
${ }^{6}$ http://eddyleks.blog.kontan.co.id/2012/08/28/perpeace-as-solution-penyelesai-sengketabisnis/

7 Pengurus Ikatan Notaris Indonesia, 100 Tahun Ikatan Notaris Indonesia Jati Diri Notaris Indonesia, Dulu, Sekarang dan di Masa Mendatang, ed.2, Ikrar Mandiriabadi, Jakarta, 2009, p. 47 
the notary is used as a "public official", so that the deed made by a notary because of his position acquires the nature of an authentic deed. ${ }^{8}$

The description of the background above, the author is interested and raises a question how is the role of a notary in settlement with peace outside the court and the responsibility of a notary in resolving disputes against a peace deed made before a notary ${ }^{9}$.

\section{Research Methods}

The research method used is a normative juridical approach, namely research which in its study refers to and bases on legal norms and rules, applicable laws and regulations, legal theories and doctrines, jurisprudence and other library materials that relevant to the research topic in accordance with the normative juridical approach, the source of data in this study is only secondary data, in the form of primary, secondary and tertiary legal materials. To obtain the necessary legal materials, this is done by searching, collecting and reviewing decision materials, laws and regulations, research results, scientific works and other written documents ${ }^{10}$.

\section{Results and Discussion}

\subsection{The Role of Notaries in Settlement With Peace Outside the Court}

Dispute resolution out of court is carried out through deliberation for consensus so that it tends to produce a win-win solution. The end result is certainly different from litigation which often decides dispute resolution through win-lose, making it difficult to provide peace and harmony for the parties. There are many types of dispute resolution outside the court such as, arbitration, negotiation, conciliation and mediation ${ }^{11}$.

The peace agreement resulting from a dispute resolution process must be stated in written form, it aims to prevent the re-emergence of the same dispute in the future. To fulfill the above, the peace process outside the court can be carried

${ }^{8}$ Ibid. p. 48
${ }^{9}$ Deen, Thaufiq., Ong Argo Victoria \& Sumain. (2018). Public Notary Services In Malaysia. JURNAL
$\begin{array}{lllll}\text { AKTA: } \quad \text { Vol. } & 5, \quad \text { No. } & 4, & 1017-1026 . & \text { Retrieved }\end{array}$ http://jurnal.unissula.ac.id/index.php/akta/article/view/4135

${ }^{10}$ Sukarmi \& Ong Argo Victoria. (2018). Cash Waqf in Sustaining Of Indonesian Society "In Legal \& Economic Perspective". AL-ITQAN: Journal of Islamic Sciences: IIUM Malaysia. https://journals.iium.edu.my/al-itqan/index.php/al-itqan/article/view/43

11 Victoria, O. A., \& ., M. (2021). Doctor's Constributions in Transportation Monitoring During COVID-19 Pandemic. KnE Social Sciences, 5(1), 598-618. https://doi.org/10.18502/kss.v5i1.8317 
out by making a deed, namely a peace deed. This deed of peace can be in the form of an underhand deed or an authentic deed made by a notary ${ }^{12}$ is an extension of the government in this case the State, where the State has given trust to a notary to carry out some state affairs or duties, especially in the field of civil law. ${ }^{13}$ The position of a Notary Responds to the community's need for neutral and balanced legal assistance so as to protect the interests of the community. Notary is a public official who is authorized to make an authentic deed and has other authorities, as referred to in Act No. 2 of 2014 concerning Notary Positions. The authority to make the authentic deed as long as it is not regulated by other laws and regulations ${ }^{14}$.

\subsection{The notary's responsibility in resolving disputes regarding the peace deed made before the notary}

As a public official, a notary must have extensive knowledge or insight, one of which is regarding the technique of making a deed that will be made later, because if the notary violates certain provisions, due to lack of knowledge ${ }^{15}$ and insight it will result in the deed he made only has the power of proof as a the deed is private, or the deed may be null and void, so that the party who suffers the loss can demand reimbursement of costs, compensation, and interest to the Notary. ${ }^{16}$

If someone is harmed because of someone else's actions, while between them there is no agreement (a legal relationship agreement), then based on the law there is also a legal relationship between the person ${ }^{17}$ that causes the loss. ${ }^{18}$ This is regulated in Article 1365 of the Civil Code, as follows: Every act that violates

\footnotetext{
${ }^{12}$ According to Abdul Ghofur Abshori, Notary is a noble profession (officium nobile) because it is very closely related to humanity. A deed made by a notary becomes the legal basis for the status of a person's property, rights and obligations. Mistakes in a notary deed can cause a person's rights to be revoked or someone's obligation to be burdened; Abdul Ghofur Anshori. 2009. Lembaga Kenotariatan Indonesia, Perspektif Hukum dan Etika, Yogyakarta: UII Press. p.25.

${ }^{13}$ Santia Dewi dan Fauwas Diradja.2011. Panduan Teori dan Praktik Notaris. Yogyakarta: Pustaka Yustisia. p.8.

${ }^{14}$ A Chuasanga, Ong Argo Victoria. (2019). Legal Principles Under Criminal Law in Indonesia Dan Thailand, Jurnal Daulat Hukum, Vol 2, No 1 (2019) http://jurnal.unissula.ac.id/index.php/RH/article/view/4218

${ }^{15}$ Alam, Bahrul., \& Khisni, Akhmad. (2020). Legal Protection of Holders of Land Loss Data In The City Land Office of Kendari. JURNAL AKTA: Vol.7, No. 2, 159-164. Retrieved from http://jurnal.unissula.ac.id/index.php/akta/article/view/7963

${ }^{16}$ Santia Dewi, OP.cit, p. 10

${ }^{17}$ Arrohim, Mohammad B., \& Wahyuningsih, Sri Endah. (2020). Analysis of Judicial Application of Criminal Penalty Against Notary / Land Deed Officials Conducting Making Crime of the Fake Authentic Deed in State Court of Semarang. JURNAL AKTA: Vol.7, No. 2, 183-188. Retrieved from http://jurnal.unissula.ac.id/index.php/akta/article/view/7891
}

${ }^{18}$ AZ Nasution, Hukum Perlindungan Konsumen, ed.2, Diapit Media, Jakarta, 2002, p.77 
the law that causes harm to another person, obliges the person who because of his mistake in issuing the loss, compensates for the loss. According to article 1365 of the Civil Code, what is meant by an unlawful act is an unlawful act committed by a person who because of his fault has caused harm to another person. In law, there are 3 (three) categories of unlawful acts, namely as follows: ${ }^{19}$
a. Acts against the law because of intentional
b. Acts against the law without error (without intentional or negligent elements)
c. Acts against the law due to negligence

Furthermore, Shidarta explained that in general the principles of responsibility in law can be distinguished as follows: ${ }^{20}$
a. Responsibility based on the element of error
b. Principle of Presumption Always to be responsible
c. The Presumption of Not Always Responsible
d. Principle of Absolute Responsibility

This concept of responsibility when associated with the notary profession, the notary can be held accountable for his mistakes and omissions in the implementation of his duties and positions. The notary is not responsible for the contents of the deed made before him, but the notary is only responsible for the formal form of the authentic deed as stipulated by law. ${ }^{21}$ The notary is not only authorized to make a deed of peace in the sense of Verlijden, namely compiling, reading and signing and Verlijkden in the sense of making a deed in the form determined by law as referred to in Article 1868 of the Civil Code, but also based on the provisions contained in Article 16 paragraph (1) letter d UUJN, namely the obligation of a Notary to provide services in accordance with the provisions of this law, unless there is a reason to refuse it. Notaries also provide legal advice and explanations regarding the provisions of the law to the disputing parties.

\section{Closing}

The role of a notary in making a peace deed is to make an authentic deed in accordance with the notary's duties contained in Article 15 of the UUJN and to formulate the wishes or actions of the parties into an authentic deed. The notary's responsibilities are born from the obligations and authorities given to

\footnotetext{
${ }^{19}$ Munir Fuady, Perbuatan Melawan Hukum, ed.1, Citra Aditya Bakti, Bandung, 2002, p.3.

${ }^{20}$ Shidarta, Op. Cit., p. 73-79

${ }^{21}$ Ibid.
} 
him, these obligations and authorities are legally and bound to take effect since the notary takes his oath of office as a notary. The oath that has been taken is the one who should control all the actions of the notary in carrying out his position. The notary's responsibility towards the parties is to express their will in a form of a peace deed, because the parties want the peace deed made by the notary to guarantee that the peace deed made is in accordance with predetermined legal rules, so that the interests of the parties are protected by the existence of the peace deed. In other words, the peace deed guarantees legal certainty. Thus, losses and disputes that will occur in the future can be avoided. The notary is not responsible for the contents of the deed made before him, but the notary is only responsible for the formal form of the authentic deed as stipulated by law. Notaries are not only authorized to make a peace deed in the Verlijden sense, namely to draw up, read and sign and Verlijkden in the sense of making a deed in the form determined by law as referred to by Article 1868 of the Civil Code, but also based on the provisions contained in Article 16 paragraph (1) letter $d$ of the UUJN, namely there is an obligation on the Notary to provide services in accordance with the provisions of this law, unless there is a reason to refuse it. Notaries also provide legal advice and explanations regarding the provisions of the law to the disputing parties namely the obligation of the Notary to provide services in accordance with the provisions of this law, unless there is a reason to refuse it. Notaries also provide legal advice and explanations regarding the provisions of the law to the disputing parties.

\section{References}

Journal:

[1] A Chuasanga, Ong Argo Victoria. (2019). Legal Principles Under Criminal Law in Indonesia Dan Thailand, Jurnal Daulat Hukum, Vol 2, No 1 (2019) http://jurnal.unissula.ac.id/index.php/RH/article/view/4218

[2] Deen, Thaufiq., Ong Argo Victoria \& Sumain. (2018). Public Notary Services In Malaysia. JURNAL AKTA: Vol. 5, No. 4, 1017-1026. Retrieved from http://jurnal.unissula.ac.id/index.php/akta/article/view/4135

[3] Sukarmi \& Ong Argo Victoria. (2018). Cash Waqf in Sustaining of Indonesian Society "In Legal \& Economic Perspective". AL-ITQAN: Journal of Islamic Sciences: IIUM Malaysia. https://journals.iium.edu.my/alitqan/index.php/al-itqan/article/view/43

[4] Victoria, O. A., \& ., M. (2021). Doctor's Constributions in Transportation Monitoring During COVID-19 Pandemic. KnE Social Sciences, 5(1), 598618. https://doi.org/10.18502/kss.v5i1.8317 
[5] Alam, Bahrul., \& Khisni, Akhmad. (2020). Legal Protection of Holders of Land Loss Data In The City Land Office of Kendari. JURNAL AKTA: Vol.7, No. 2, 159-164. Retrieved from http://jurnal.unissula.ac.id/index.php/akta/article/view/7963

[6] Arrohim, Mohammad B., \& Wahyuningsih, Sri Endah. (2020). Analysis of Judicial Application of Criminal Penalty Against Notary / Land Deed Officials Conducting Making Crime of the Fake Authentic Deed in State Court of Semarang. JURNAL AKTA: Vol.7, No. 2, 183-188. Retrieved from http://jurnal.unissula.ac.id/index.php/akta/article/view/7891

Books:

[1] AZ Nasution, Hukum Perlindungan Konsumen, ed.2, Diapit Media, Jakarta, 2002

[2] Maria SW Sumardjono, Nurhasan Ismail, Isharyanto, Mediasi Sengketa Tanah, Kompas, Gramedia, Jakarta, 2008

[3] Abdul Ghofur Anshori. 2009. Lembaga Kenotariatan Indonesia, Perspektif Hukum dan Etika, Yogyakarta: UII Press.

[4] Munir Fuady, Perbuatan Melawan Hukum, ed.1, Citra Aditya Bakti, Bandung, 2002

[5] Pengurus Ikatan Notaris Indonesia, 100 Tahun Ikatan Notaris Indonesia Jati Diri Notaris Indonesia, Dulu, Sekarang dan di Masa Mendatang, ed.2, Ikrar Mandiriabadi, Jakarta, 2009

[6] Rachmadi Usman I, 2003, Pilihan Penyelesaian Sengketa di Luar Pengadilan, PT. Citra Aditya Bakti, Bandung

[7] Santia Dewi dan Fauwas Diradja.2011. Panduan Teori dan Praktik Notaris. Yogyakarta: Pustaka Yustisia.

Internet:

[1] http://eddyleks.blog.kontan.co.id/2012/08/28/perdamaiansebagai-solusi-penyelesaian-sengketa-bisnis/

[2] http://eprints.unram.ac.id/5685/1/SKRIPSI.pdf, accessed on 10 June 2020 at 06:40

[3] http://repositori.usu.ac.id/bitstream/handle/123456789/483/147 011135.pdf? sequence $=1$ \&isAllowed $=y$

[4] https://media.neliti.com/media/publications/164877-ID-analisisyuridis-atas-peran-notaris-terh.pdf 